\title{
What can we learn from REE abundances in clinopyroxene and orthopyroxene in residual spinel peridotites?
}

\author{
YAN LIANG ${ }^{1}$, ZEJIA JI ${ }^{1,2}$, AND BODA LIU ${ }^{1,3}$ \\ ${ }^{1}$ Brown University, ${ }^{2}$ Peking University, ${ }^{3}$ Rice University \\ yan_liang@brown.edu
}

Clinopyroxene (cpx) is the major repository of REE in spinel peridotites. Most geochemical studies of REE in mantle samples focus on cpx. Recent advances in in situ trace element analysis has made it possible to accurately measure REE in orthopyroxene (opx). Abundances of REE in cpx and opx have been routinely reported in the literature. The purpose of this study is to determine what additional information one can learn about mantle processes from REE abundances in opx coexisting with cpx in spinel peridotites.

Processes that can affect REE abundances in pyroxenes in residual peridotites include partial melting, melt extraction, and subsolidus re-equilibration. Here we use a multi-mineral disequilibrium melting model and a subsolidus reequilibration model to simulate REE fractionation during decompression melting and subsolidus cooling. We use REE abundances in the bulk spinel peridotite xenoliths and abyssal peridotites to invert melting parameters and REE abundances in coexisting opx and cpx to assess the subsolidus effect. Main conclusions based on case studies of 9 residual spinel peridotite xenoliths and 12 residual abyssal peridotites can be summarized as follows. (1) It is more reliable to deduce melting parameters from REE in the bulk peridotite than in cpx. We do not recommend the use of REE in cpx alone to infer the degree of melting of mantle xenolith, as HREE in cpx are reset by subsolidus re-equilibration. (2) Composition of the primitive mantle (PM) is more suitable for modeling REE depletion in mantle xenoliths than the composition of DMM. (3) LREE in opx and HREE in cpx are more susceptible to subsolidus redistribution. The extent of redistribution depends on the modes of cpx and opx in the sample and thermal history experienced by the peridotite. By modeling subsolidus redistribution of REE between opx and cpx after melting, we show that it is possible to discriminate mineral mode of the starting mantle and cooling rate experienced by the peridotite sample. Results from the present study suggest that endmembers of DMM and PM are not homogeneous in mineral mode. A modally heterogeneous peridotitic starting mantle provides a simple explanation for the large variations of mineral mode observed in mantle xenoliths and abyssal peridotites. 